\title{
Efektifitas Pencatatan Pemeriksaan Faktor Risiko Tinggi Ibu Hamil dalam Menekan Angka Kematian Ibu (AKI) di Wilayah Puskesmas Karang Duren Kecamatan Balung Kabupaten Jember
}

\author{
Fikhy Rizky Hapsari ${ }^{1}$, Novita Nuraini ${ }^{2}$, Rossalina Adi Wijayanti ${ }^{2 *}$ \\ ${ }^{1}$ Puskesmas Karang Dureng, Indonesia \\ ${ }^{2}$ Jurusan Kesehatan, Politeknik Negeri Jember, Indonesia \\ Email : rossa@polije.ac.id*
}

\begin{abstract}
Abstrak
Angka kematian ibu merupakan indikator kesejahteraan perempuan, indikator kesejahteraan suatu bangsa sekaligus menggambarkan hasil capaian pembangunan suatu negara. Informasi mengenai Angka Kematian Ibu akan sangat bermanfaat untuk pengembangan program program peningkatan kesehatan ibu. Kabupaten Jember menduduki peringkat 2 (dua) untuk angka kematian ibu tertinggi di Jawa Timur Tahun 2016. Puskesmas Karang Duren merupakan salah satu puskesmas di Kabupaten Jember yang memiliki Angka Kematian Ibu Tahun 2011, 2012, 2013. Penelitian bertujuan mengetahui efektifitas pencatatan pemeriksaan faktor risiko tinggi ibu hamil dalam menekan Angka Kematian Ibu (AKI) dengan cara melakukan komparasi kepatuhan petugas dalam pencatatan dengan formulir lama dan baru yang kemungkinan besar berhubungan dengan AKI. Penelitian ini merupakan penelitian observasional analitik. Sampel penelitian ini adalah sebagian petugas petugas program KIA di wilayah Puskesmas Karang Duren Kecamatan Balung Kabupaten Jember berjumlah 10 petugas dengan teknik simple random sampling dan pengambilan sampel dilakukan pada bulan Januari sampai dengan Maret Tahun 2017. Variabel dalam penelitian ini terdiri dari kepatuhan pencatatan petugas dengan formulir lama dan baru. Data yang diperoleh diolah dengan software pengolahan data dan dianalisis menggunakan uji Mann Whitney. Hasil penelitian menunjukkan sebagian besar kepatuhan petugas rendah dalam pencatatan pemeriksaan faktor risiko tinggi ibu hamil menggunakan formulir lama, ditunjukkan dengan ketidaklengkapan formulir lama sebesar $60 \%$. Kepatuhan petugas tinggi dalam pencatatan pemeriksaan faktor risiko tinggi ibu hamil menggunakan formulir baru menunjukkan bahwa sebagian besar petugas melengkapi pengisian formulir baru sebesar $90 \%$. Terdapat perbedaan kepatuhan petugas dalam pencatatan menggunakan formulir lama dan baru dengan nilai $\mathrm{P}$ value $=0,002$ dengan nilai alpha $=0,05$. Pencatatan pemeriksaan faktor risiko tinggi ibu hamil menggunakan formulir baru menunjukkan kelengkapan lebih tinggi dari pada pencatatan menggunakan formulir lama. Hal ini menunjukkan bahwa formulir baru efektif dalam upaya mendeteksi faktor risiko. Kelengkapan formulir ditindaklanjuti dengan penanganan segera. Deteksi faktor risiko pada ibu hamil merupakan salah satu upaya penting dalam mencegah kematian dan kesakitan ibu.
\end{abstract}

Kata Kunci : Formulir Pencatatan, Kepatuhan petugas, Angka Kematian Ibu (AKI)

\section{Pendahuluan}

Angka kematian ibu merupakan indikator kesejahteraan perempuan, indikator kesejahteraan suatu bangsa sekaligus menggambarkan hasil capaian pembangunan suatu negara. Informasi mengenai Angka Kematian Ibu akan sangat bermanfaat untuk pengembangan program program peningkatan kesehatan ibu, terutama pelayanan kehamilan dan persalinan yang aman, program peningkatan jumlah persalinan yang ditolong oleh tenaga kesehatan, manajemen sistim rujukan dalam penanganan komplikasi kehamilan, persiapan keluarga hingga suami siaga dalam menyongsong kelahiran, yang pada gilirannya merupakan upaya menurunkan Angka Kematian
Ibu dan meningkatkan derajat kesehatan reproduksi (Chalid, 2015).

Kabupaten Jember merupakan salah satu kabupaten yang terdapat di Propinsi Jawa Timur. Pada tahun 2016, Kabupaten Jember menduduki peringkat 2 (dua) untuk angka kematian ibu tertinggi di Jawa Timur.

Menurut hasil Survei Kesehatan Rumah Tangga (SKRT) Tahun 2001, penyebab langsung kematian hampir $90 \%$ terjadi saat persalinan dan segera setelah persalinan (Chalid, 2015). Sementara itu, risiko kematian ibu juga makin tinggi akibat adanya faktor keterlambatan, yang menjadi penyebab tindak langsung kematian ibu. Terdapat tiga risiko keterlambatan, yaitu terlambat mengambil keputusan untuk dirujuk (termasuk terlambat mengenali bahaya), terlambat sampai 
fasilitas kesehatan pada saat keadaan darurat dan terlambat memperoleh pelayanan yang memadai oleh tenaga kesehatan (Chalid, 2015).

Chalid (2015) menyebutkan penyebab kematian ibu masih berputar pada masalah utama (perdarahan, preklampsia-eklampsia dan infeksi), sehingga pencegahan dan penanggulangan masalah ini seharusnya difokuskan melalui intervensi pada ketiga masalah tersebut, melalui peran petugas kesehatan. Petugas kesehatan dapat berupa dokter dan bidan yang memang secara professional mempunyai peran menurunkan angka kematian ibu. Dokter dan bidan adalah garda terdepan dalam mendeteksi kemungkinan risiko, mendorong program Keluarga Berencana (KB), melakukan asuhan antenatal terfokus, pencegahan abortus tidak aman, pertolongan persalinan oleh tenaga terampil, rujukan dini tepat waktu kasus gawat darurat obstetri dan pertolongan segera - adekuat kasus gawat darurat obstetri di rumah sakit rujukan. Penolong yang terampil pada saat sebelum, selama dan sesudah persalinan telah terbukti mempunyai peran dalam menurunkan kematian ibu (Chalid, 2015).

Pusat Kesehatan Masyarakat (Puskesmas) memiliki peranan utama dan sangat vital dalam upaya penurunan AKI di Indonesia. Programprogram kesehatan di Puskesmas difokuskan pada kegiatan preventif dan promotif dalam program Kesehatan Ibu dan Anak. Selain itu salah satu upaya terobosan adalah Program Perencanaan Persalinan dan Pencegahan Komplikasi (P4K). Program dengan menggunakan "stiker" ini, dapat meningkatkan peran aktif suami (suami Siaga), keluarga dan masyarakat dalam merencanakan persalinan yang aman. Program ini juga meningkatkan persiapan menghadapi komplikasi pada saat kehamilan, termasuk perencanaan pemakaian alat/obat kontrasepsi pasca persalinan. Selain itu, program $\mathrm{P} 4 \mathrm{~K}$ juga mendorong ibu hamil untuk memeriksakan kehamilan, bersalin, pemeriksaan nifas dan bayi yang dilahirkan oleh tenaga kesehatan terampil termasuk skrining status imunisasi tetanus lengkap pada setiap ibu hamil. Kaum ibu juga didorong untuk melakukan inisiasi menyusu dini (IMD) dilanjutkan pemberian ASI eksklusif.

Berhasil tidaknya sebuah program besar kemungkinan dipengaruhi oleh pengelolaan dalam program tersebut. Program kesehatan ibu yang melibatkan peran bidan sebagai petugas kesehatan dengan menggunakan pengololaan yang baik memungkinkan dapat menurunkan kejadian kematian yang berakibat menurunkan AKI.

Puskesmas Karang Duren merupakan salah satu puskesmas di Kabupaten Jember yang berlokasi di Kecamatan Balung. Hasil laporan terakhir menunjukkan Tahun 2011, 2012, 2013 memiliki Angka Kematian Ibu. Oleh karena itu diperlukan manajemen yang baik dalam pelaksanaan kegiatan Program Kesehatan Ibu dan Anak (KIA). Salah satu kegiatan yang dapat dilakukan dengan upaya evaluasi kepatuhan petugas terhadap pencatatan rekam medis ibu hamil melalui penggunaan kartu ibu, karena pencatatan sebelumnya dilakukan di kohort Ibu tidak mencakup keseluruhan data ibu hamil, dan pencatatan di Buku KIA yang dibawa pulang oleh ibu Hamil. Sehingga dapat dirumuskan kepatuhan petugas yang merupakan bentuk perilaku kerja mungkin berpengaruh terhadap Angka Kematian Ibu (AKI).

Menurut Ilyas (2002) menyebutkan bahwa perilaku kerja dan kinerja individu (Job performance) merupakan faktor yang mempengaruhi efektifitas organisasi. Kepatuhan petugas dalam pencatatan pemeriksaan faktor risiko tinggi ibu hamil merupakan bentuk perilaku kerja (work behavior). Hal ini sesuai dengan pendapat Ilyas (2002) bahwa perilaku yang berpengaruh terhadap kinerja adalah yang berkaitan dengan tugas-tugas pekerjaan yang harus diselesaikan untuk mencapai sasaran suatu jabatan atau tugas. Selanjutnya, menurut Ivancevich (2007) juga menjelaskan perilaku kerja adalah semua hal yang dilakukan seseorang dalam lingkungan pekerjaan. Menurut Moeheriono (2009) menyebutkan kedisiplinan atau kepatuhan merupakan kesediaan untuk teratur dan tertib dalam bekerja agar tidak menghambat pelaksanaan tugas, sehingga berdasarkan pengertian tersebut

\section{Metodologi}

Penelitian ini merupakan penelitian observasional analitik. Penelitian bertujuan mengetahui efektifitas pencatatan pemeriksaan faktor risiko tinggi ibu hamil dalam menekan Angka Kematian Ibu (AKI) dengan cara melakukan komparasi kepatuhan petugas dalam pencatatan dengan formulir lama dan baru yang kemungkinan besar berhubungan dengan AKI.

Penelitian ini dilakukan di Wilayah Puskesmas Karang Duren Kecamatan Balung Kabupaten Jember. Waktu penelitian adalah bulan Januari sampai dengan Maret Tahun 2017.

Populasi dalam penelitian ini adalah seluruh petugas program KIA di wilayah Puskesmas Karang Duren Kecamatan Balung Kabupaten Jember berjumlah 11 petugas. Sampel penelitian ini adalah sebagian petugas petugas program KIA di wilayah Puskesmas Karang Duren Kecamatan Balung Kabupaten Jember berjumlah 10 petugas dengan teknik simple random sampling. Pengumpulan data dilakukan dengan observasi dengan bantuan checklist pada formulir lama dan baru. 
Hasil analisis merupakan pengolahan data observasi pada formulir lama dan baru yang diolah dengan software pengolahan data dengan tujuan komparasi. Uji komparasi untuk mengetahui efektifitas pencatatan faktor risiko ibu hamil menggunakan formulir lama dan baru (dilihat dari kepatuhan petugas), skala data yang digunakan berskala ordinal. Pemilihan uji dilakukan setelah melakukan pengujian normalitas data terlebih dahulu. Teknik uji menggunakan uji Mann Whitney dengan menyesuaikan kerangka konseptual penelitian yang terdiri dari dua Variabel, diantaranya variable independen dan dependen. Variabel Independen terdiri dari Work behaviour (Kepatuhan/disiplin pencatatan dengan formulir lama) dan Work behaviour (kepatuhan/disiplin pencatatan dengan formulir baru). Variabel dependen terdiri dari Job performance (Pencapaian hasil kerja atau target petugas/perhitungan skor resiko ibu hamil).

\section{Hasil dan Pembahasan}

Di Puskesmas Karang Duren Kecamatan Balung Kabupaten Jember terdapat 11 bidan yang bertugas melakukan pencatatan. Kepatuhan merupakan kesediaan untuk teratur dan tertib dalam bekerja agar tidak menghambat pelaksanaan tugas (Moeheriono, 2009). Sehingga kelengkapan pencatatan formulir yang dilakukan oleh bidan dapat merupakan gambaran kepatuhan.

Identifikasi kepatuhan petugas dalam pencatatan pemeriksaan faktor risiko tinggi ibu hamil berdasarkan kelengkapan pengisian setiap komponen formulir dimana kepatuhan rendah, jika formulir tidak lengkap (terisi $<85$ poin) dan kelengkapan tinggi, jika formulir lengkap (terisi > 85 poin)

Hasil observasi kepatuhan petugas dalam melakukan pencatatan pemeriksaan faktor risiko tinggi ibu hamil dalam menekan Angka Kematian Ibu (AKI) adalah sebagai berikut:

\subsection{Identifikasi Kepatuhan Petugas dalam Pencatatan Pemeriksaan Faktor Risiko Tinggi Ibu Hamil dengan Formulir Lama}

Berdasarkan hasil penelitian didapatkan sebagian besar kepatuhan petugas rendah dalam pencatatan pemeriksaan faktor risiko tinggi ibu hamil menggunakan formulir lama. Hal ini ditunjukkan dengan ketidaklengkapan formulir lama sebesar $60 \%$. Hasil penelitian dapat dilihat pada Tabel 3.1.
Tabel 3.1 Kepatuhan Petugas dalam Pencatatan Pemeriksaan Faktor Risiko Tinggi Ibu Hamil dengan Formulir Lama

\begin{tabular}{lcc}
\hline \multicolumn{1}{c}{ Kepatuhan } & N & Persentase (\%) \\
\hline Lengkap & 4 & $40 \%$ \\
Tidak lengkap & 6 & $60 \%$ \\
\hline Jumlah & 10 & $100 \%$ \\
\hline
\end{tabular}

Tingginya ketidaklengkapan petugas dalam pengisian formulir pencatatan pemeriksaan faktor risiko tinggi ibu hamil menggunakan formulir lama kemungkinan disebabkan karena formulir yang kurang sederhana. Pencatatan pemeriksaan faktor risiko tinggi ibu hamil dengan formulir lama menggunakan kohort. Hasil wawancara menunjukkan sebagian petugas merasa formulir lama kurang memadai. Komponen risiko tinggi ibu hamil hanya terdeteksi secara umum. Berikut adalah komponen pencatatan dalam formulir lama diantaranya, Identitas ibu, Riwayat Obstetrik/ kehamilan, Pemeriksaan Bidan, Pendeteksi faktor risiko, Jarak kehamilan, Imunisasi TT, Tanggal Kunjungan Ibu, Penolong persalinan, Kelahiran dan Ibu nifas.

Besar kemungkinan kepatuhan pencatatan yang terbukti dengan rendahnya kelengkapan kohort ibu dapat menyebabkan masih ditemukannya AKI di Puskesmas Karang Duren Kecamatan Balung Kabupaten Jember. Akibat beberapa komponen yang belum lengkap maka pencegahan timbulnya kematian ibu tidak maksimal. Hasil ini sesuai dengan anjuran WHO untuk mendapatkan AKI yang paling baik adalah menindak lanjuti kohor ibu hamil (Senewe dan Wiryawan, 2011).

\subsection{Identifikasi Kepatuhan Petugas dalam Pencatatan Pemeriksaan Faktor Risiko Tinggi Ibu Hamil dengan Formulir Baru}

Tabel 3.2 Kepatuhan Petugas dalam Pencatatan Pemeriksaan Faktor Risiko Tinggi Ibu Hamil dengan Formulir Baru

\begin{tabular}{lcc}
\hline \multicolumn{1}{c}{ Kepatuhan } & $\mathrm{N}$ & Persentase (\%) \\
\hline Lengkap & 9 & $90 \%$ \\
Tidak lengkap & 10 & $10 \%$ \\
\hline Jumlah & 10 & $100 \%$ \\
\hline
\end{tabular}

Hasil penelitian menunjukkan kepatuhan petugas tinggi dalam pencatatan pemeriksaan faktor risiko tinggi ibu hamil. Hasil observasi menunjukkan bahwa sebagian besar petugas melengkapi pengisian formulir baru sebesar $90 \%$.

Kelengkapan pengisian formulir pencatatan pemeriksaan faktor risiko tinggi ibu hamil baru diidentifikasi melalui beberapa komponen terdiri dari Identitas ibu, Riwayat obstetric, Pemeriksaan 
Bidan, Rencana pesalinan, Asuhan persalinan, Pemeriksaan PNC, Kunjungan Nifas dan Register Ibu. Setiap komponen masih terbagi menjadi beberapa informasi. Sehingga jika semua komponen terpenuhi maka faktor risiko ibu hamil terdeteksi dini.

Komplikasi dalam kehamilan dan persalinan tidak selalu dapat diduga sebelumnya, semua persalinan harus ditolong oleh tenaga kesehatan agar komplikasi kebidanan dapat segera dideteksi dan ditangani serta diarahkan ke fasilitas pelayanan kesehatan. Sebagian besar kematian ibu dapat dicegah apabila mendapat penanganan yang adekuat difasilitas pelayanan kesehatan serta faktor waktu dan transportasi merupakan hal yang sangat menentukan dalam merujuk kasus risiko tinggi. Deteksi faktor risiko pada ibu hamil baik oleh tenaga kesehatan maupun masyarakat merupakan salah satu upaya penting dalam mencegah kematian dan kesakitan ibu (Ristrin dan Oktarina, 2014).

Hasil penelitian tentang kelengkapan pengisian formulir pencatatan pemeriksaan faktor risiko tinggi ibu hamil baru besar kemungkinan menyebabkan menurunnya AKI di Puskesmas Karang Duren Kecamatan Balung Kabupaten Jember. Karena dengan telah dilakukannya pencacatan yang lengkap kejadian AKI dapat ditekan. Hal ini sesuai dengan pernyataan yang disampaikan oleh kepala Puskesmas Karang Duren Kecamatan Balung Kabupaten Jember. Serta adanya monitoring dan evaluasi yang rutin oleh kepala Puskesmas Karang Duren Kecamatan Balung Kabupaten Jember juga besar kemungkinan menekan AKI.

\subsection{Efektifitas Pencatatan Pemeriksaan Faktor Risiko Tinggi Ibu Hamil dalam Menekan Angka Kematian Ibu (AKI) di Wilayah Puskesmas Karang Duren (Komparasi Kepatuhan Formulir Lama dan Baru)}

Dalam penelitian ini, dilakukan uji statistik untuk mengetahui efektifitas pencatatan pemeriksaan faktor risiko tinggi ibu hamil dalam menekan Angka Kematian Ibu (AKI) di Wilayah Puskesmas Karang Duren. Uji statistik yang dilakukan adalah uji komparasi kepatuhan pencatatan menggunakan formulir lama dan baru.

Hasil penelitian ini menunjukkan bahwa ada perbedaan kepatuhan petugas dalam pencatatan menggunakan formulir lama dan baru dengan nilai $P$ value $=0,002$ dengan nilai alpha $=0,05$. Pencatatan pemeriksaan faktor risiko tinggi ibu hamil menggunakan formulir baru menunjukkan kelengkapan lebih tinggi dari pada pencatatan menggunakan formulir lama. Hal ini menunjukkan bahwa formulir baru efektif dalam upaya mendeteksi faktor risiko. Kelengkapan formulir ditindaklanjuti dengan penanganan segera.

Besar kemungkinan petugas merasa lebih mudah melakukan pengisian formulir baru, karena komponen formulir yang telah dijabarkan menjadi lebih sederhana. Komplikasi dalam kehamilan dan persalinan tidak selalu dapat diduga sebelumnya, semua persalinan harus ditolong oleh tenaga kesehatan agar komplikasi kebidanan dapat segera dideteksi dan ditangani serta diarahkan ke fasilitas pelayanan kesehatan. Sebagian besar kematian ibu dapat dicegah apabila mendapat penanganan yang adekuat difasilitas pelayanan kesehatan serta faktor waktu dan transportasi merupakan hal yang sangat menentukan dalam merujuk kasus risiko tinggi. Deteksi faktor risiko pada ibu hamil baik oleh tenaga kesehatan maupun masyarakat merupakan salah satu upaya penting dalam mencegah kematian dan kesakitan ibu (Ristrin dan Oktarina, 2014).

\section{Kesimpulan}

Berdasarkan hasil penelitian efektifitas pencatatan pemeriksaan faktor risiko tinggi ibu hamil dalam menekan Angka Kematian Ibu (AKI) Di wilayah Puskesmas Karang Duren Kecamatan Balung Kabupaten Jember dapat ditarik kesimpulan sebagai berikut:

a. Sebagian besar kepatuhan petugas rendah dalam pencatatan pemeriksaan faktor risiko tinggi ibu hamil menggunakan formulir lama. Hal ini ditunjukkan dengan ketidaklengkapan formulir lama sebesar $60 \%$.

b. Kepatuhan petugas tinggi dalam pencatatan pemeriksaan faktor risiko tinggi ibu hamil menggunakan formulir baru menunjukkan bahwa sebagian besar petugas melengkapi pengisian formulir baru sebesar $90 \%$.

c. Hasil penelitian ini menunjukkan bahwa ada perbedaan kepatuhan petugas dalam pencatatan menggunakan formulir lama dan baru dengan nilai $P$ value $=0,002$ dengan nilai alpha $=0,05$. Pencatatan pemeriksaan faktor risiko tinggi ibu hamil menggunakan formulir baru menunjukkan kelengkapan lebih tinggi dari pada pencatatan menggunakan formulir lama. Hal ini menunjukkan bahwa formulir baru efektif dalam upaya mendeteksi faktor risiko. Kelengkapan formulir ditindaklanjuti dengan penanganan segera. 
ISSN : 2354-5852

e-ISSN : 2579-5783

\section{Daftar Pustaka}

(1) Chalid, M T. 2015. Upaya Menurunkan Angka Kematian Ibu: Peran Petugas Kesehatan. Departemen Obstetri dan Ginekologi. Fakultas Kedokteran. Universitas Hasanuddin. PT. Gakken.

(2) Ivancevich, JM, Robert, K \& Michael, TM 2007, Perilaku dan Manajemen Organisasi, Jilid I, Penerbit Erlangga, Jakarta.

(3) Ilyas, Y 2002, Kinerja Teori, Penilaian, Dan Penelitian, Pusat Kajian Ekonomi Kesehatan Fakultas Kesehatan Masyarakat Universitas Indonesia, Jakarta.

(4) Moeheriono 2009, Pengukuran Kinerja Berbasis Kompetensi, Penerbit Ghalia Indonesia, Bogor.

(5) Ristrin dan Oktarina, 2014, Upaya Peningkatkan Deteksi Dini Risiko Tinggi Kehamilan Melalui Kelengkapan Pengisian Buku Kia Oleh Bidan Di Kabupaten Bangkalan Jawa Timur Tahun 2013. Buletin Penelitian Sistem Kesehatan - Vol. 17 No. 3 Juli 2014: 215-225.

(6) Senewe, FP \& Wiryawan, Y, 2011.

(7) Pencatatan dan pelaporan sistem pemantauan

(8) wilayah setempat - kesehatan ibu dan anak oleh bidan di desa di Puskesmas Sepatan Kabupaten Tangerang 2008. Jurnal Ekologi Kesehatan Volume 10 No. 3. 